\title{
ANALYSIS OF LAND USE/LAND COVER CHANGES FOLLOWING POPULATION MOVEMENTS AND AGRICULTURAL ACTIVITIES: A CASE STUDY IN NORTHERN TURKEY
}

\author{
ŞEN, G. ${ }^{1 *}-$ GÜNGÖR, E. ${ }^{2}$ \\ ${ }^{1}$ Faculty of Forestry, Kastamonu University, 37200 Kastamonu, Turkey \\ (phone: +90-532-562-5998; fax: +90-366-215-2316) \\ ${ }^{2}$ Faculty of Forestry, Bartın University, 74100 Bartın, Turkey \\ (phone: +90-532-628-3318; fax: +90-378-223-5069) \\ *Corresponding author \\ e-mail: gsen@kastamonu.edu.tr; phone: +90-532-562-5998; fax: +90-366-215-2316 \\ (Received $15^{\text {th }}$ Jan 2018; accepted $26^{\text {th }}$ Mar 2018)
}

\begin{abstract}
This study analyzes the changes in spatial and temporal patterns of land use/cover from 1999 to 2014 in the city of Kastamonu, which is located at the center of the western Black Sea Region of Turkey. In this study, Kastamonu constitutes the study area, which is $65 \%$ covered with forests. Remote sensing, geographical information systems, and economic and demographic variables have been used for the analysis. The results showed that $0.2 \%$ of forested areas have been converted to settlement areas, and $8.5 \%$ have been converted to agricultural lands during this period. On the other hand, $12.5 \%$ of settlement areas and $30.4 \%$ of agricultural lands were transformed into forested area in the same period. A net increase of $15.1 \%$ (108768.2 ha) happened in forest areas between 1999 and 2014. The annual percentage of forestation for forest areas within the study period was $0.94 \%$ in Kastamonu. In Kastamonu, the most important factor in the increase of forested areas is demographic movement, which decreased agriculture and animal husbandry due to declining populations in rural areas between 1999-2017. The abandoned agricultural areas have turned into forest areas. Grazing pressure on forests has decreased with the decrease in animal husbandry. This has been effective in structural improvements and spatial increase of forest areas. However, the development of substitute products in wood, widespread use of solar energy systems in rural areas, and the construction of more insulated buildings are other factors that are effective in increasing forest areas.
\end{abstract}

Keywords: spatiotemporal analysis, land use/cover change, socio-economic impact on forest, Kastamonu, Turkey

\section{Introduction}

The importance of forest ecosystems is ever increasing, as forested ecosystems maintain the Earth's ecological balance. Pollution and destructive effects from rapid increases in population coupled with rapid industrial development require us to be more sensitive about forests (Seçkin, 1995). In fact, forest areas simultaneously fulfill many ecological, economic, social, and esthetic functions. Forested areas provide many important functions such as reducing all types of air pollution (Yigit et al., 2016; Sevik et al., 2016), reduce noise (Aricak et al., 2016), have a psychologically positive effect (Cetin and Sevik, 2016a), help save energy (Cetin and Sevik, 2016b), and are an important economic resource (Tunçtaner et al., 2007; Sevik, 2012); further, they prevent erosion (Özel et al., 2015; Sevik et al., 2017), reduce wind speed, hold soil through their roots and prevent rain and streams from carrying the soil away, and protect wild life and hunting sources (URL1, 2004; Güneş Şen and Aydın, 2017). Furthermore, open green 
areas with plants are important for human activity (Ertekin and Özel, 2010; Cetin et al., 2017; Özel and Ertekin, 2012). These functions, therefore, play a greater role, particularly in highly populated areas. However, when the amount and structure of forested area change, there may be problems in completely fulfilling these functions.

The history of permanent forest destruction dates back to the Neolithic period (Kaplan et al., 2009; Ostlund et al., 2015). However, destruction started to occur during the Industrial Revolution at the end of the eighteenth century (Simpson et al., 2003). According to research by the Food and Agriculture Organization, 16 million ha of forested area were lost between 1990 and 2000, and 13 million ha of forested area were lost between 2000 and 2010 (FAO, 2010). In fact, forest destruction occurs because of the effect of various factors such as ecological (tree species, composition, etc.), natural regeneration capacity, productivity and natural disasters (Ostlund et al., 2015; Trbojevic et al., 2012).

The effects of forest destruction do not remain at a regional level and may have a global impact. According to previous studies, deforestation is the second-largest source of anthropogenic carbon dioxide emissions and causes a net reduction of carbon storage in terrestrial ecosystems (De Sy, et al., 2015). Moreover, forest destruction leads to various effects, such as a decrease in biological diversity, endemics of rare living creatures, and even loss of generations (De Sy et al., 2015; Ochoa-Quintero et al., 2015; Barlow et al., 2016). According to the results of a study conducted in South America, the total deforested area and related gross carbon losses from 1990 to 2005 reached 57.7 million ha and 6.460 gigatonnes of carbon, respectively (De Sy, et al., 2015). In other studies, the deforestation rate was reported to be 3.74-4.09 million ha per year in 1990s and 3.28-4.87 million ha per year in 2000s (Hansen et al., 2010; Harris et al., 2012; Eva et al., 2012; Achard et al., 2014). Carbon loss related to deforestation was calculated as 306-698 petagrams per year in 1990s and 322-845 petagrams of carbon per year in 2000s (Baccini et al., 2012; Harris et al., 2012; Eva et al., 2012; Achard et al., 2014; Houghton, 2012; Tyukavina et al., 2015). Therefore, the loss in forested area is not only a loss of the ecosystem but also has numerous consequences, some of which occur on the global scale and may directly or indirectly affect people, plants, and animals.

Outstanding factors among the causes of forest destruction are as follows: changes in land use; turning forested areas into agricultural or settlement areas; climate changes; and forest fires (Chauchard et al., 2010; Schweizer et al., 2017; Kucuk et al., 2017; Cabral and Costa, 2017). Previous studies have suggested that each of these three factors are fundamentally human-derived. Forested areas are destructed and used for different purposes to fulfill the demands of the increasing population, and the change in the global climate arising from the destruction of the ecosystem caused by human activities damages the forested areas at a significant level. In addition, > 90\% of forest fires break out as a result of human activities (Harvey, 2016; Šturm and Podobnikar, 2017).

However, human activities (i.e., anthropogenic factors) are the biggest factor that contributes to forest destruction. At this point, economic activities, population sizes, and people's beliefs emerge as the main factors determining the impact of human activities in a forest (Ostlund et al., 2015; Bayramoğlu and Kadığulları, 2018). High-quality forested areas are intensely exposed to the human effect because of plank timber production. Pressure from rural and urban populations cause legal and illegal increases in these utilizations. With respect to changes in population and movements, forests are positively affected on the one hand and negatively affected on the other. To maintain 
and manage the biodiversity, it is important to understand the dynamics of forest losses and consequences of human effects, which are the leading cause for such losses (Puyravaud, 2003; Lele and Joshi, 2009; Sen et al., 2015). In this context, such areas should be continuously monitored, and solutions should be developed to avoid current inconveniences and pressures on forests. This monitoring is particularly crucial for biologically rich areas. In this manner, contemporary data would be obtained for sustainable forest management, which would allow decision makers to perform more accurate analyses.

In this study, we analyzed the spatial and temporal changes in land use and land cover during 1999-2014 in Kastamonu City, which is in the Black Sea Region in northwest Turkey. In addition, some socio-economic variables have been examined in relation to changes in the land use/cover. This study fills the gap through a large-scale analysis of land use/cover change using stand-type maps occurring in air photo data, particularly focusing on the Kastamonu forests during the 1999-2017 period.

\section{Study area}

Kastamonu Province is located in the western part of the Black Sea Region in Turkey between the north latitudes of 41-42 and east longitudes of 33-46 (Fig. 1). Its surface area is $13108 \mathrm{~km}^{2}$ (Öztürk and Özdemir, 2013).

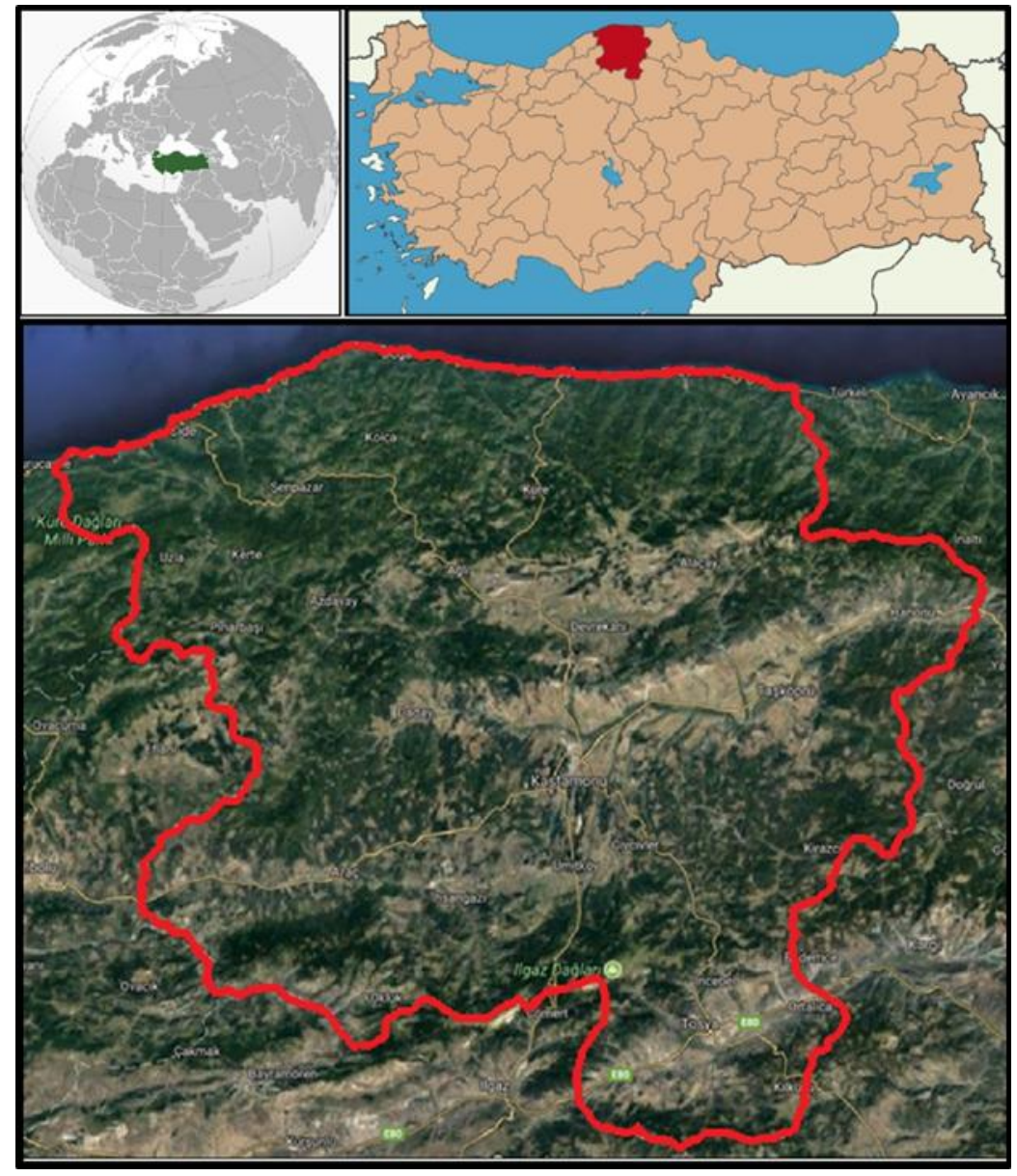

Figure 1. Geographic location of the Kastamonu Province 
There are two national parks in the study area: The Küre Mountains National Park, which that Protected Areas Network parks certification, and the Ilgaz Mountain National Park (Anonymous, 2014; Öztürk and Ayan, 2015). Moreover, the Küre Mountains are home to five distinct habitat types, which are categorized as endangered habitats, as per the Bern Conventions (BERN) (KMNP, 2017).

Ilgaz Mountain National Park (IMNP) contains approximately 10\% of plant species in Turkey; 64 of these plant species are endemic. IMNP has been identified as one of Turkey's most important plant areas by WWF. The protected natural forests in the IMNP create suitable habitats for many mammal species. Grizzly bear, deer, wolf, fox, wild boar, roe deer, rabbit and otter are some of the mammals in this area (URL2, 2016). At the same time, IMNP is recognized as one of the "97 Important Bird Areas" in Turkey due to predatory birds (URL3, 2017). Another important point in terms of species diversity is the Küre Mountains National Park. In this national park, 1050 plant species, including 158 endemic species, have been identified (URL2, 2016); 59 of these plant taxa are endangered (URL3, 2017).

More than $65 \%$ of Kastamonu is covered with forest; $48 \%$ of the general area is productive productive woodland; $17 \%$ is degraded forest; and $35 \%$ is forestless (URL4, 2017; Güneş Şen, 2015).

In Kastamonu, economically the most important sector is agriculture. Agricultural activity depends on vegetative production and forestry because the country is located on a rich forest belt. The agricultural area covers only $28 \%$ of the total land of the province. There are some agricultural products in this area, e.g., wheat, barley, and potatoes. Sugar beets, cannabis, and garlic are also produced as industrial crops (URL5, 2014; URL6, 2006). According to 2017 data, the population of Kastamonu is around 360366 persons. The population makes up approximately $0.5 \%$ of the country's population. Forty-eight percent of the population live in the city center, and the remaining population live in districts and villages (TUIK, 2017). The population status of Kastamonu Province according to the years is shown in Table 1. There are 21 municipalities, including the city center and 1071 villages in the Kastamonu Province.

Table 1. Urban and rural population of Kastamonu Province (2000-2015)

\begin{tabular}{c|c|c|c}
\hline Years & Urban population & Rural population & Total population \\
\hline 2000 & 174020 & 201456 & 375476 \\
2007 & 184685 & 175681 & 360366 \\
2010 & 196162 & 165060 & 361222 \\
2015 & 226868 & 145765 & 372633 \\
\hline
\end{tabular}

As shown in Table 1, the total population decreased by 2843 persons $(0.8 \%)$ in Kastamonu. When we look at the rural population, it can be seen that the decline in the population is almost $28 \%$.

\section{Materials and methods}

There are various methods for collecting, analyzing, and presenting natural resources data to explain forest dynamics. In particular, the use of remote sensing and geographic information systems (GIS) can greatly shorten and simplify the analysis process 
(Gautam et al., 2003). Analysis of temporal changes in area use and covers in Kastamonu Province was performed in two steps. In the first step, stand-type maps for 1999, 2009, and 2014 were quantified and rectified using Arc/Info GIS, and a data set was created for temporal change analysis. In the second step, temporal changes and transitions in the land cover were analyzed.

This study used data-gathered stand-type maps produced by the General Directorate of Forestry for years 1999, 2009, and 2014. These maps were then scanned and registered at the 1:25000 scale using first-order nearest-neighbor rules with UTM projection. We then used ArcGIS ${ }^{\circledR}$ software to overlay the maps and compute changes in land area over time as well as changes between classes of land cover and/or land use (Cakir et al., 2008).

A rough-level classification approach was employed in the study area. Classification refers to a broad simplification of large land-use types and land covers defined by type composition and nonforested areas (Karahalil et al., 2009). Eleven land cover classes were included in the analysis (Table 2).

Table 2. Land use/land cover classes description

\begin{tabular}{c|c|c}
\hline & AL & Agricultural land \\
& SA & Settlement areas \\
W & PM & Areas covered with standing water \\
& PPC & Productive mixed wood \\
Land use/cover & PPB & Productive* pure stands composed of coniferous trees \\
& DPC & Productive pure stands composed of broad-leaved trees \\
& DPB & Degraded $^{* *}$ pure stands composed of coniferous trees \\
& DM & Degraded pure stands composed of broad-leaved trees \\
& OA & Degraded mixed wood \\
& AF & Forest land, meadow, and mining field \\
\hline
\end{tabular}

*Productive forest (PF): Productive forest with a $>10 \%$ estimated tree crown cover

*** Degraded forest (DF): Degraded forest with a $<10 \%$ estimated tree crown cover

In addition, forest management plans and information about demographic change, economic conditions, and living standards of local people were obtained and evaluated to determine socio-economic factors and administrative intervention influencing changes in land use.

After that, the data were analyzed to identify changes in land use and land cover over time; the study supplemented these findings by examining forest management plans and socio-demographic data to understand potential contributors to the changes of land use and land cover.

The annual rate of decrease or increase should be also revealed to the impact of a decrease in forest sources on the protection of biodiversity. For this purpose, the annual rate of forestation was calculated using Equation 1 (Puyravaud, 2003).

$$
P=\left(\frac{1}{t_{2}-t_{1}} \ln \frac{A_{2}}{A_{1}}\right) \times 100
$$


where $P$ is the percentage of forestation/deforestation per year, and $A_{1}$ and $A_{2}$ are the amount of forest cover at time points $t_{1}$ and $t_{2}$, respectively.

In addition to those listed above, changes that have occurred in forested areas and population movements, which are considered to have the greatest impact on this change, as well as the number of large and small cattle, amount of arable land, and yield of farming activities were comparatively evaluated and interpreted.

\section{Results}

\section{Spatial and temporal changes in land use/cover}

The land use/cover status of Kastamonu Province for the years 1999, 2009, and 2014 were determined as a result of analyses. The results are shown in Table 3 and Figures 2, 3 , and 4 .

Table 3. Evolution of selected landscape variables in the study area from 1999 to 2014

\begin{tabular}{c|c|c|c|c|c|c}
\hline Year & \multicolumn{2}{|c|}{1999} & \multicolumn{2}{c|}{$\mathbf{2 0 0 9}$} & \multicolumn{2}{c}{$\mathbf{2 0 1 4}$} \\
\hline Class & ha & \% & ha & \% & ha & \% \\
\hline OA & 23560.2 & 1.85 & 312.4 & 0.02 & 6040.3 & 0.48 \\
AF & 8624.3 & 0.68 & 2721.7 & 0.21 & 2745.9 & 0.22 \\
DPC & 49423.6 & 3.89 & 79833.5 & 6.28 & 78315.7 & 6.17 \\
DM & 85434.1 & 6.73 & 10315.7 & 0.81 & 10621.9 & 0.84 \\
DPB & 111002.2 & 8.74 & 89508.0 & 7.05 & 88627.9 & 6.98 \\
SA & 21059.2 & 1.66 & 23152.4 & 1.82 & 23489.8 & 1.85 \\
W & 454.0 & 0.04 & 1020.8 & 0.08 & 1000.7 & 0.08 \\
PPC & 222055.4 & 17.48 & 360646.5 & 28.39 & 360529.6 & 28.38 \\
PM & 112648.2 & 8.87 & 127449.8 & 10.03 & 125227.2 & 9.86 \\
PPB & 139947.2 & 11.02 & 163217.5 & 12.85 & 165956.6 & 13.06 \\
AL & 496053.6 & 39.05 & 412083.9 & 32.44 & 407706.4 & 32.10 \\
\hline Grand total & 1270262.1 & 100.00 & 1270262.1 & 100.00 & 1270262.1 & 100.00 \\
\hline
\end{tabular}

The forested area in Kastamonu Province is 832024.8 ha, according to the stand-type maps from forest management plans. This area constitutes $63.5 \%$ of the Kastamonu Province. On the basis of analysis performed in 1999, approximately $39.05 \%, 1.66 \%$, $19.36 \%, 37.37 \%$, and $56.72 \%$ of the total area subject to analysis was calculated as the agricultural area, settlement area, degraded area, productive land, and forested area, respectively; whereas, in 2009, approximately $32.44 \%, 1.82 \%, 14.14 \%, 51.27 \%$, and $65.42 \%$ of the total area were calculated as the agricultural area, settlement area, degraded area, productive land, and forested area, respectively. In 2014, the ratio of the settlement area in Kastamonu increased to $1.85 \%$, while the ratio of the agricultural area decreased to $32.10 \%$, but there was no significant change in the forested area, and the ratio of forested to total area was $65.28 \%$. 


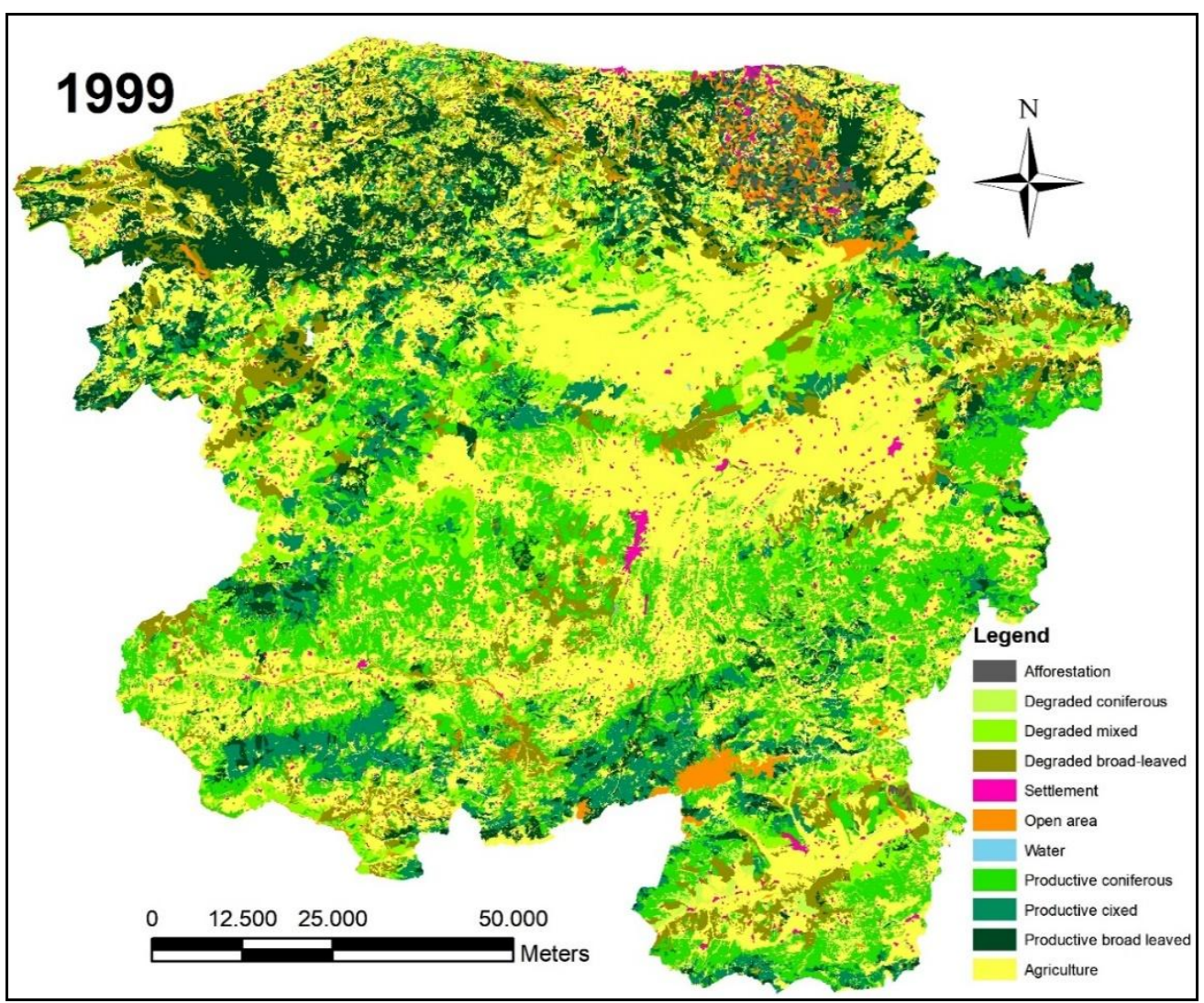

Figure 2. Land use/cover status of Kastamonu Province in 1999

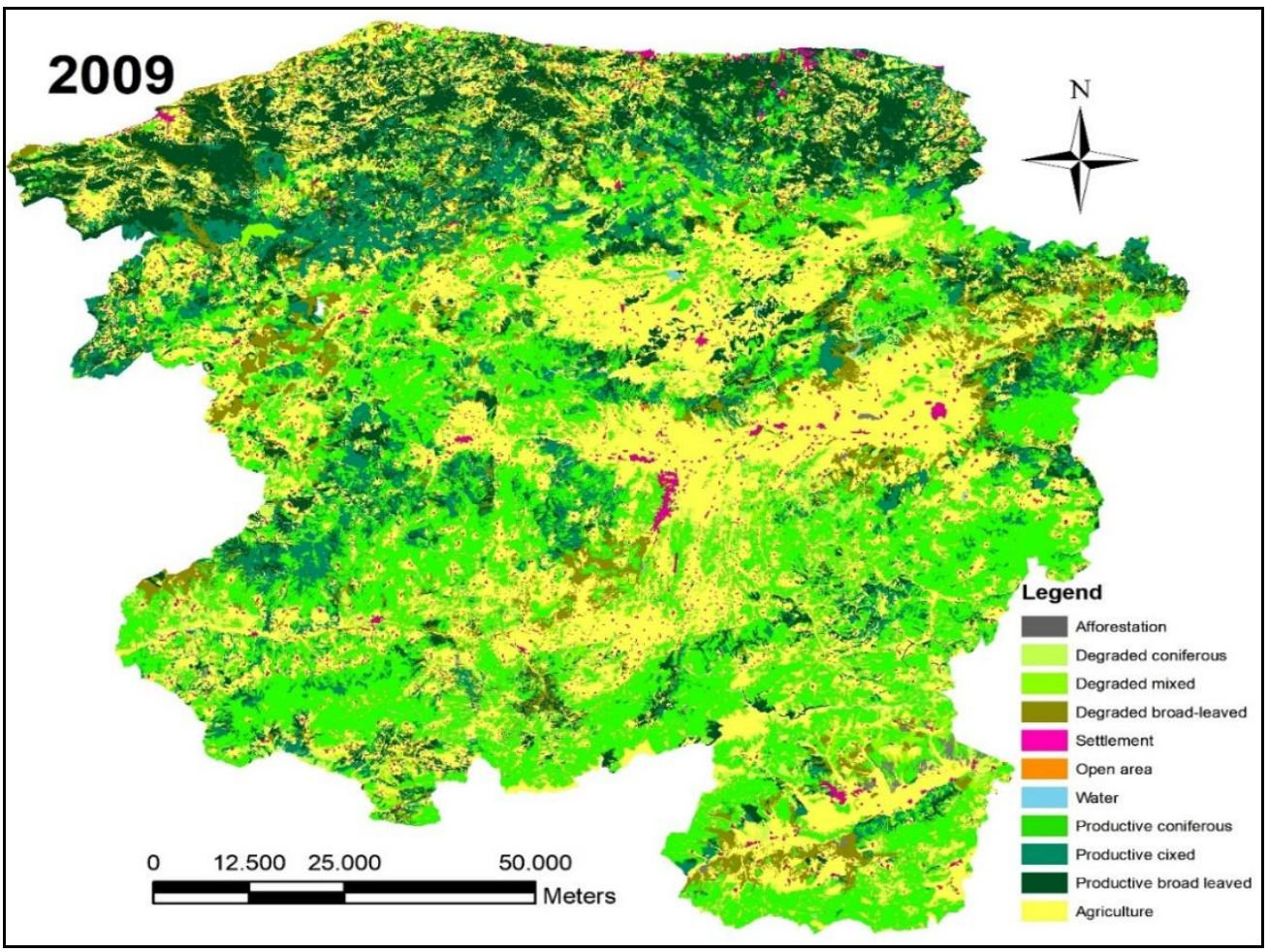

Figure 3. Land use/cover status of Kastamonu Province in 2009 


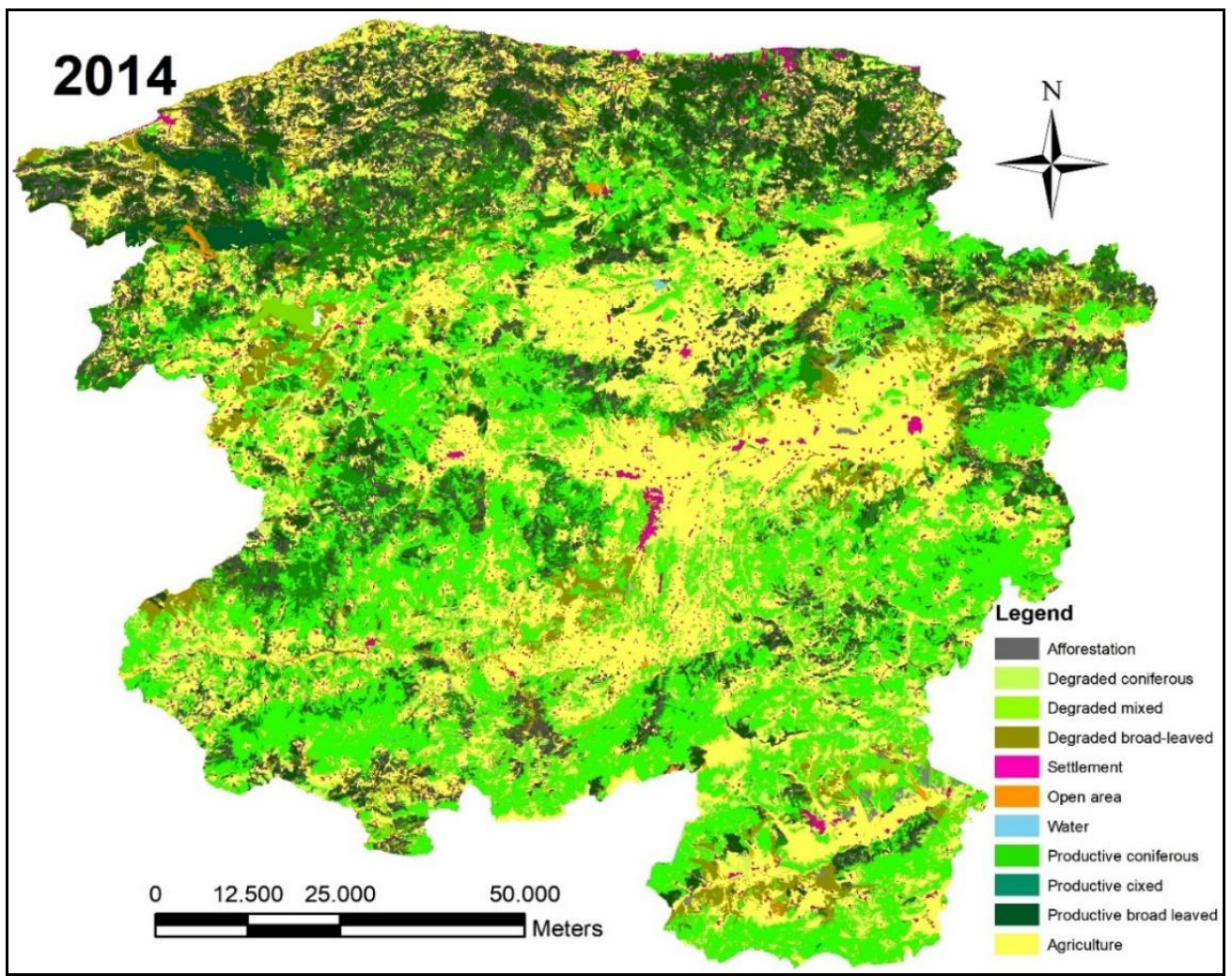

Figure 4. Land use/cover status of Kastamonu Province in 2014

\section{Transition among land use/land cover types}

The results of analyses regarding the use of land use/cover in Kastamonu are shown in Tables 4, 5, and 6.

Table 4. Transition matrix of land use/cover changes in Kastamonu Province from 1999 to 2009

\begin{tabular}{c|c|c|c|c|c|c|c|c|c|c|c}
\hline \multicolumn{1}{c}{$\begin{array}{c}\text { 1999-2009 } \\
\text { fhanged }\end{array}$} & OA & AF & DPC & DM & DPB & SA & W & PPC & PM & PPB & AL \\
\hline OA & 39.9 & 2.9 & 1491 & 21.4 & 2183.1 & 132.3 & 88.7 & 2099.9 & 1313.2 & 6496.4 & 9691.6 \\
AF & 0 & 314.6 & 204.5 & 30.4 & 327.6 & 31.1 & 0 & 1532.7 & 1449.9 & 4378.5 & 355 \\
DPC & 3.7 & 111.2 & 18514.5 & 805.9 & 3628.7 & 115.5 & 12 & 17396.8 & 2700.3 & 1304.9 & 4830 \\
DM & 12.6 & 241.3 & 14625 & 5356.2 & 8526.9 & 87.8 & 24.3 & 20690.4 & 18556.4 & 11880.4 & 5432.7 \\
DPB & 27 & 345.2 & 6791.7 & 1592.2 & 40408.3 & 123.5 & 41 & 11173.7 & 11406.9 & 28983.1 & 10109.6 \\
SA & 25.9 & 11 & 226.8 & 28.2 & 280.7 & 12467.2 & 5.7 & 393.9 & 183.6 & 619.9 & 6816.2 \\
W & 1.5 & 0 & 14.5 & 0 & 3.9 & 3.5 & 203.3 & 4.1 & 12.1 & 24.9 & 186.2 \\
PPC & 51.1 & 652.2 & 8955 & 690.5 & 2652.8 & 189.4 & 22.7 & 175744.8 & 20511.3 & 5182.9 & 7402.8 \\
PM & 0.1 & 40.3 & 3873.6 & 133 & 5583.7 & 43.3 & 72.9 & 65018.5 & 22932.4 & 11041.4 & 3909.2 \\
PPB & 0.5 & 0.9 & 1726.5 & 77.1 & 4406.7 & 72.2 & 8.4 & 26157.8 & 35480.4 & 68194.3 & 3822.3 \\
AL & 150 & 1002.3 & 23410.4 & 1580.6 & 21505.6 & 9886.7 & 541.8 & 40434 & 12903.1 & 25110.7 & 359528.4 \\
\hline
\end{tabular}


Table 5. Transition matrix of land use/cover changes in Kastamonu Province from 2009 to 2014

\begin{tabular}{c|c|c|c|c|c|c|c|c|c|c|c}
\hline $\begin{array}{c}\text { Changed } \\
\text { from }\end{array}$ & OA & AF & DPC & DM & DPB & SA & W & PPC & PM & PPB & AL \\
\hline OA & 117.1 & 0 & 6.9 & 0.5 & 6.7 & 14.5 & 1 & 33.4 & 28.6 & 24.3 & 79.3 \\
AF & 3.6 & 2124.8 & 53.5 & 49.4 & 42 & 4.1 & 1.4 & 228.2 & 2.2 & 14.2 & 198.3 \\
DPC & 191.3 & 50.3 & 44784.9 & 87.2 & 2311 & 239.5 & 25.7 & 17789.7 & 2509 & 2061.4 & 9783.5 \\
DM & 29.5 & 29.6 & 254.8 & 6755.3 & 135.6 & 25.6 & 1.3 & 1354.8 & 272 & 267 & 1190.3 \\
DPB & 379.3 & 60.1 & 1444.1 & 229.5 & 61181.9 & 297.3 & 59.5 & 4978.7 & 3266.7 & 7629.1 & 9981.7 \\
SA & 66.7 & 14.3 & 345 & 28.4 & 383 & 13750.2 & 8.1 & 521.1 & 190.4 & 389.3 & 7456.1 \\
W & 31.4 & 0 & 47.8 & 0.9 & 66.2 & 8.1 & 604.2 & 24.9 & 8.4 & 24.6 & 204.4 \\
PPC & 306.9 & 193.5 & 16898.5 & 1358 & 4704.2 & 534.6 & 19.8 & 289959.6 & 12679 & 7720.1 & 26272.3 \\
PM & 111.6 & 6.4 & 2559 & 272.6 & 3372.1 & 200.3 & 12.7 & 11646.5 & 92376.8 & 9754.9 & 7136.8 \\
PPB & 415.5 & 8.2 & 2026.5 & 344.9 & 7995 & 490 & 50.3 & 7280.2 & 8289.9 & 120952.3 & 15364.7 \\
AL & 3829.2 & 254.7 & 10013.1 & 1100.8 & 11305.6 & 7909.7 & 213.3 & 26325.4 & 6818.4 & 15185.3 & 329128.3 \\
\hline
\end{tabular}

Table 6. Transition matrix of land use/cover changes in Kastamonu Province from 1999 to 2014

1999-2014

\begin{tabular}{c|c|c|c|c|c|c|c|c|c|c|c}
\hline $\begin{array}{c}\text { Changed } \\
\text { from }\end{array}$ & OA & AF & DPC & DM & DPB & SA & W & PPC & PM & PPB & AL \\
\hline OA & 1771.1 & 5.5 & 1429.7 & 21.5 & 1819.4 & 167.2 & 51.2 & 2714 & 1363.7 & 6300.3 & 7916.6 \\
AF & 16.1 & 287.8 & 214.4 & 41.2 & 388.8 & 77.1 & 0 & 1468.2 & 1367.9 & 4200.9 & 561.9 \\
DPC & 107.2 & 116.9 & 13233 & 723.6 & 3403.4 & 226.7 & 13.2 & 20399.5 & 2290.5 & 1609.4 & 7300.1 \\
DM & 277.2 & 249.4 & 12939.7 & 4186.2 & 8166.6 & 170 & 24.5 & 22646.1 & 17705.8 & 11600.2 & 7468.6 \\
DPB & 877 & 354.5 & 5876.1 & 1730.4 & 34279.9 & 267.1 & 69.9 & 12741.7 & 11572.5 & 29290 & 13943.3 \\
SA & 70.8 & 18.2 & 396.1 & 46.1 & 470.4 & 9323.5 & 8.2 & 675.1 & 280.4 & 771.4 & 8998.9 \\
W & 28.8 & 0 & 28.8 & 0.9 & 26.1 & 4.8 & 126.3 & 15.9 & 20.2 & 29.8 & 172.4 \\
PPC & 227.8 & 615.2 & 13211.2 & 1360.5 & 3891.3 & 403.5 & 45.4 & 157223.9 & 21131.3 & 6845.4 & 17099.9 \\
PM & 86.2 & 38.7 & 4883.1 & 237.6 & 5715 & 123.6 & 81 & 62788.5 & 21239.5 & 10773.7 & 6681.3 \\
PPB & 214.8 & 5.5 & 2373.8 & 251.9 & 6267.5 & 213.2 & 12.1 & 25655.7 & 32878.8 & 63401.3 & 8672.7 \\
AL & 2363.3 & 1054.2 & 23729.8 & 2022.2 & 24199.6 & 12513.2 & 568.9 & 54201 & 15376.7 & 31134.2 & 328890.6 \\
\hline
\end{tabular}

Areal and qualitative improvements in forested areas have attracted increasing attention. An increase of approximately $35 \%$ in total productive forested areas from 1999 to 2014 has drawn attention, while $65.56 \%$ of degraded forests in 1999 maintained their degraded forest quality in 2014. Approximately $42 \%$ of degraded coniferous forests turned into productive coniferous forests, and $8 \%$ of these forests turned into productive leaved or mixed forest, while $26 \%$ of degraded broad-leaved forests turned 
into productive broad-leaved forest; $22 \%$ of these forests turned into productive mixed or productive coniferous forest, and $>60 \%$ of degraded mixed forests turned into productive forest. Approximately $24 \%$ of productive forest also turned into degraded forested area from 1999-2014. Apart from that, > 30\% of agricultural areas turned into forested areas, and $2.52 \%$ of these areas turned into settlement areas; whereas $66.3 \%$ of these areas maintained their agricultural area quality. This ratio indicates that the agricultural area was the highest-rated area that turned into settlement areas.

\section{Analysis of the forestation/deforestation rate}

Forestation/deforestation ratios of Kastamonu were determined for 1999-2009, 2009-2014, and 1999-2014. Ratios obtained from this analysis are shown in Table 7.

Table 7. Forestation/deforestation ratios of Kastamonu Province

\begin{tabular}{c|c|c|c}
\hline & $\mathbf{1 9 9 9 - 2 0 0 9}$ & $\mathbf{2 0 0 9 - 2 0 1 4}$ & $\mathbf{1 9 9 9 - 2 0 1 4}$ \\
\hline Productive forest & 3.16 & 0.01 & 2.11 \\
Degraded forest & -3.14 & -0.23 & -2.17 \\
Total forest & 1.43 & -0.04 & 0.94 \\
\hline
\end{tabular}

As shown in Table 7, productive forests have a positive forestation rate, while degraded forests have a negative value, that is, degraded forests generally decrease. The annual forestation ratio from 1999 to 2009 decreased to $3.16 \%$ for productive forests and to $-3.14 \%$ for degraded forests. The annual forestation ratio from 2009 to 2014 decreased to $0.01 \%$ for productive forests. The deforestation ratio for degraded forests decreased and regressed to $-0.23 \%$. When the study period is evaluated in general, the annual forestation ratio for the general forestation area was $0.94 \%$. The forestation ratio for degraded forests was negative, while this ratio was positive for productive forests.

\section{Discussion}

This study particularly indicates that significant changes have occurred in the forest structure, and the changes show similar results of other studies conducted in Turkey. Previous studies showed that the current forested area increased by $15 \%$ during 19992014 (107768.2 ha). However, despite the decrease of $28 \%$ (68294.4 ha) in the degraded forest areas, the productive forest areas increased from 37\% (177062.6 ha). In a study covering the period from 1987 to 2000 in the Kastamonu Province, it was determined that 111466 ha of forest area have increased, while open areas of 112888 ha have decreased. In this period, forested areas increased by $8.43 \%$ in total (Turan et al., 2010). Similar results were obtained in a study conducted in the Daday District of Kastamonu. In the study, it was determined that the productive forest areas in the Daday region increased by $92.4 \%$ between 1970 and 2010. On the other hand, corrupt forested areas decreased by $57.7 \%$ (Zengin et al., 2018). These results show that forested areas in Kastamonu are steadily increasing. In 1987, 32.1\% of Kastamonu was covered with forest (Turan et al., 2010), while it increased to 63.5\% in 2017. 
Similar results were obtained by studies in Turkey. In a study conducted in Gümüşhane Province, it was determined that forested areas increased by $6.54 \%(6928$ ha), and the annual forestation ratio increased to 0.50\% during 1987-2000 (Kadiogullar1 and Başkent, 2008). In a study conducted in Macka, located in the northeast of Turkey, it was determined that high mountain forests showed an increase of 200.6 ha during 1973-2008 (Sen et al., 2015). In a study conducted in Koprulu Canyon, Karahalil et al. (2009) found that the percentage of stands decreased by 5.6\% during 1965-1984 and increased by $8.04 \%$ during 1984-2008. The cumulative forest accretion accounted for $1.9 \%$ (548.7 ha) of the whole area of NP. This rate translates to an annual amount of 12.7 ha forest improvement (Karahalil et al., 2009).

It could be thought that two important factors are effective in changing the land use/cover in Kastamonu. The first effective factor is population movement, especially immigration from rural areas to city centers and other cities, which is important for land use/cover changes in the area (Table 1). The change in Kastamonu's urban population during 1990-2015 is shown in Table 1. According to the results presented in this table, the urban population of Kastamonu decreased to 372633 persons as of 2015, whereas the total urban population was 423611 persons in 1990. The rural population decreased from 274901 persons in 1990 to 145765 persons in 2015, whereas the urban population increased from 148710 persons in 1990 to 226868 persons in 2015 . When these figures are evaluated in general, it is observed that the urban population in 2015 is approximately 1.5 times more than the urban population in 1990. The rural population decreased by approximately 47\% from 1990 to 2015. This is an indicator of mass migration from village to town. Along with urban-suburban migration, there is also population migration from the province to the other provinces. The total population, which was 423611 in 1990 , declined by $12 \%$ in 2015 to 372633 . These migratory movements could have different effects on land use and cover. Conversion of agricultural land to forest as a result of a decrease in rural population has been the main factor for increase in forests (Fig. 5). It was determined that agricultural areas were converted to forested and settlement areas. Although the decrease in rural population has a positive impact on forests, population increase in city centers leads to conversion of forested areas into settlement areas. In total, 1404.1 ha of forested area was converted to settlement areas during 1990-2014.

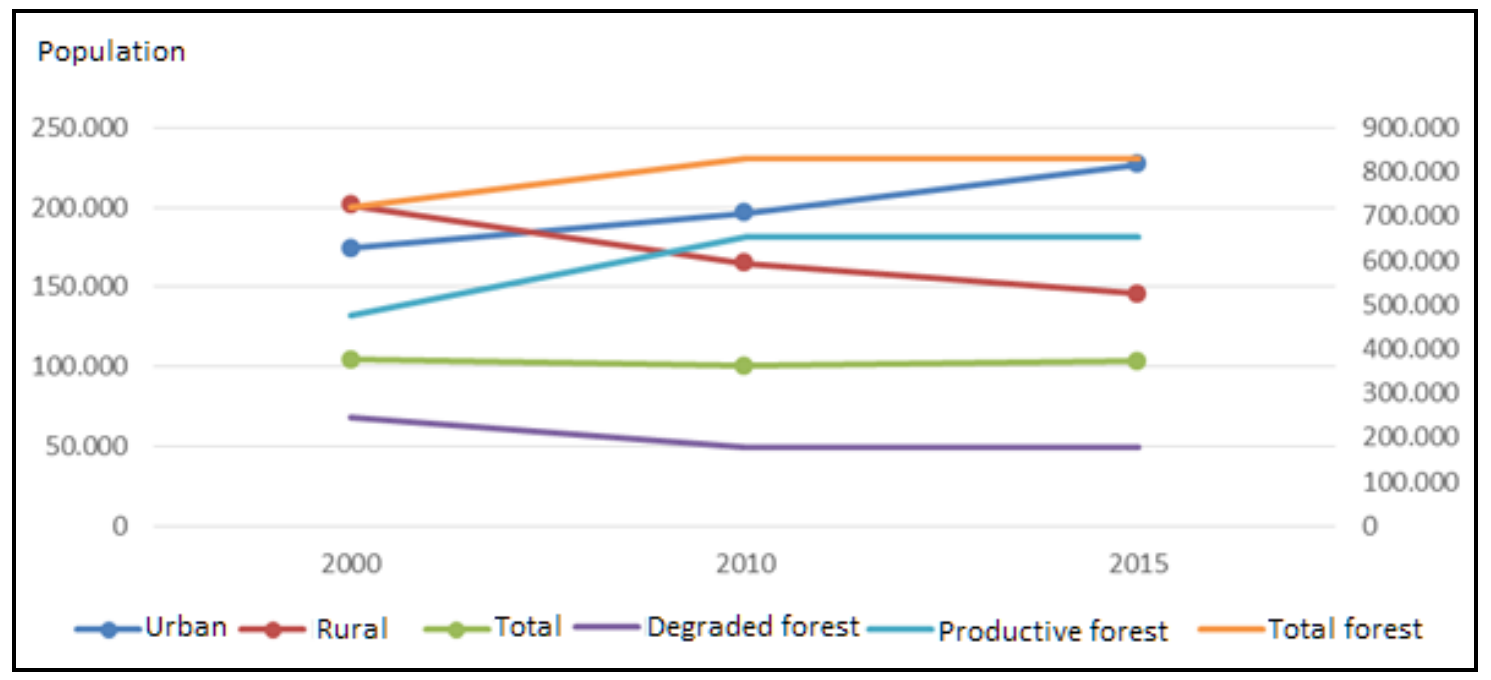

Figure 5. Population of Kastamonu Province and changes in forested areas 
When sectoral distribution of gross value added was reviewed, it was observed that the share of the agricultural sector in the developmental zone, including Kastamonu (Sinop, Cankır1, and Kastamonu), is $22.6 \%$; it is well above Turkey's average, which is $9.5 \%$. This study showed that the poverty ratio in the region is high. Agricultural lands in the region are small because of forested areas and their topography. The grains and feed crops have the highest share in plant production. The most significant agricultural activity in conformity with the regional structure is the husbandry activities. The husbandry activities are generally performed by small-scale family enterprises (URL5, 2014). Figure 6 shows the changes in livestock numbers, amount of arable land, and grain and vegetable production.

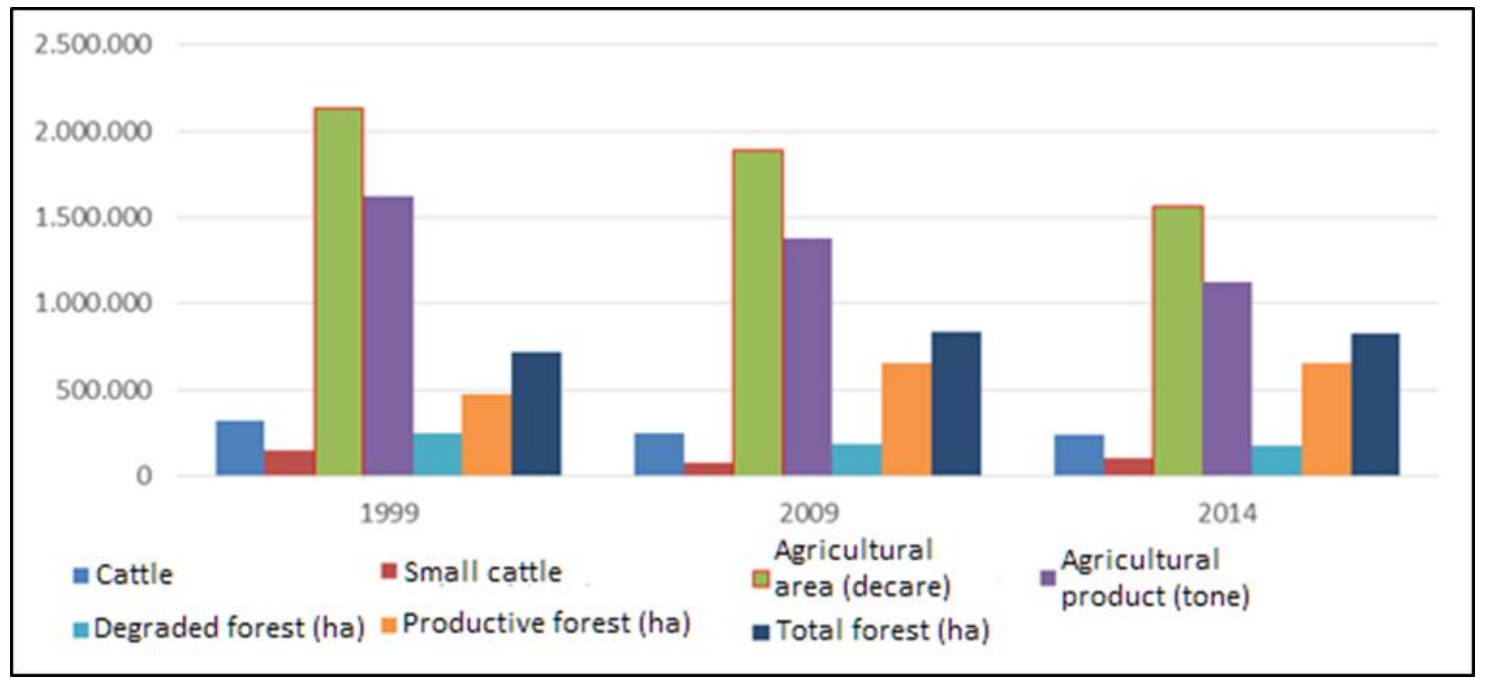

Figure 6. Agricultural variables and changes in forested areas in Kastamonu Province (19992014)

The decrease in agricultural activities along with changes in rural population also affect forests. In parallel with the decline in animal numbers, grazing pressure on the forest areas of the animals has decreased. In addition, the use of forests for fuel, lumber, and animal feed by the rural population has decreased. The decrease in all these pressures could have a positive impact on forest growth.

Between 1970 and 2010, in the study conducted in the Daday region of Kastamonu, it was determined that agricultural areas decreased by $57 \%$ in parallel with the decrease of the rural population. Particularly, it has stated that the young population leaving the villages is effective in this decrease. This study also found that population movements were concentrated in the city center (Zengin et al., 2018). Another study conducted for Kastamonu Province stated that the main reason for the increase of forest area between 1987-2000 was the population increase (Turan et al., 2010). However, the Kastamonu Forest Regional Directorate found that land use/change is also affected by afforestation activities. The afforestation contributed to the increase of forest areas and the transformation of degraded forest areas into productive forest areas. 


\section{Conclusions}

This study investigated the spatial changes in land use/cover in Kastamonu in detail. The effects of changes in population and agriculture on forested areas were also revealed. Between 1999 and 2014, forested areas in Kastamonu increased by $15.1 \%$ in total. In this period, productive forest areas increased by $37.3 \%$ while degraded forested areas decreased by $27.8 \%$. In the same period, the SAs increased by $11.5 \%$, and the ALs decreased by $17.8 \%$. During this change, $42.1 \%$ of open areas and $69.6 \%$ of agriculture areas have turned into forest areas; $47.2 \%$ of degraded forest areas have turned into productive forest areas. At the same time, $0.2 \%$ of forest areas and $2.5 \%$ of agricultural areas have been converted into settlement areas. The most important factor influencing this change is the migration from rural to urban, particularly after the 1980s. Societies are dynamic, and this dynamism affects the Earth's surface. Therefore, understanding the spatiotemporal changes in land use/cover and associated factors and the dynamics in change are important for sustainable planning of natural resources. However, all those factors should be studied in more detail on the human factor, which has the most influence on this change.

Monitoring and evaluation remain important. These analyses are particularly important for the sustainable management of ecosystems and efficient use of natural resources. For this reason, this monitoring must be elaborated upon and give weight to studies, particularly those in which socio-economic variables and human influence effects on land use are identified.

Acknowledgements. This research did not receive any specific grant from funding agencies in the public, commercial, or nonprofit sectors. Gökhan Şen and Ersin Güngör designed the research, coordinated the data analysis, and wrote the paper. Thanks to Burak Arıcak and Hakan Şevik at Kastamonu University for all the help. The authors declare no conflict of interest.

\section{REFERENCES}

[1] Achard, F., Beuchle, R., Mayaux, P., Stibig, H. J., Bodart, C., Brink, A., et al. (2014): Determination of tropical deforestation rates and related carbon losses from 1990 to 2010. - Global Change Biology 20(8): 2540-2554.

[2] Anonymous (2014): Kastamonu province state of the environment report 2014. - T. C. Kastamonu Valiliği Çevre ve Şehircilik İl Müdürlüğü: 174. Kastamonu, Turkey. http://webdosya.csb.gov.tr/db/ced/editordosya/Kastamonu\%202014.pdf (accessed on 13.06.2017).

[3] Aricak B, Enez K, Özer Genc, C, Sevik, H. (2016): A method study to determine buffering effect of the forest cover on particulate matter and noise isolation. - 1st International Symposium of Forest Engineering and Technologies (FETEC 2016), pp. 177-185.

[4] Baccini, A., Goetz, S. J., Walker, W. S., Laporte, N. T., Sun, M., Sulla-Menashe, D., et al. (2012): Estimated carbon dioxide emissions from tropical deforestation improved by carbon-density maps. - Nature Climate Change 2: 182-185.

[5] Barlow, J., Lennox, G. D., Ferreira, J., Berenguer, E., Lees, A. C., Mac Nally, R., et al. (2016): Anthropogenic disturbance in tropical forests can double biodiversity loss from deforestation. - Nature 535(7610): 144-147.

[6] Bayramoğlu, M. M., Kadıoğulları, A. (2018): Analysis of land use change and forestation in response to demographic movement and reduction of forest crime. - EURASIA 
Journal of Mathematics, Science and Technology Education 14(1): 225-238: DOI: 10.12973/ejmste/79640.

[7] Cabral, A. I. R., Costa, F. L. (2017): Land cover changes and landscape pattern dynamics in Senegal and Guinea Bissau borderland. - Applied Geography 82: 115-128.

[8] Cakir, G., Sivrikaya, F., Keleş, S. (2008): Forest cover change and fragmentation using Landsat data in Maçka State Forest Enterprise in Turkey. - Environmental Monitoring and Assessment 137: 51-66.

[9] Cetin, M., Sevik, H. (2016a): Evaluating the recreation potential of Ilgaz Mountain National Park in Turkey. - Environmental Monitoring and Assessment 188(1): 1-10.

[10] Cetin, M., Sevik, H. (2016b): Measuring the Impact of Selected Plants on Indoor CO2 Concentrations. - Polish Journal Environmental Studies. 25(3): 973-979.

[11] Cetin, M., Sevik, H., Isınkaralar, K. (2017): Changes in the particulate matter and CO2 concentrations based on the time and weather conditions: The case of Kastamonu. Oxidation Communications 40(1-2): 477-485.

[12] Chauchard, S., Beilhe, F., Denis, N., Carcaillet, C. (2010): An increase in the upper treelimit of silver fir (Abiesalba Mill.) in the Alps since the mid-20th century: A land-use change phenomenon. - Forest Ecology and Management 259(8): 1406-1415.

[13] De Sy, V., Herold, M., Achard, F., Beuchle, R., Clevers, J. G. P. W., Lindquist, E. et al. (2015): Land use patterns and related carbon losses following deforestation in South America. - Environmental Research Letters 10(12): 124004.1-15. DOI: 10.1088/17489326/10/12/124004.

[14] Ertekin, M., Özel, H. B. (2010): Black Pine (Pinus nigra Arnold.) and Lebanon Cedar (Cedrus libani A. Rich.) Plantations for Erosion Control in Çorum Region. - International Journal of Bartın Forestry Faculty 12(18): 77-85.

[15] Eva, H. D., Achard, F., Beuchle, R., de Miranda, E. E., Carboni, S., Seliger, R., et al. (2012): Forest cover changes in tropical South and Central America from 1990 to 2005 and related carbon emissions removals. - Remote Sensing 4(5): 1369-1391.

[16] FAO (2010): Global Forest Resources Assessment 2010. Main Report. - FAO Forestry Paper \#163.244 Rome, Italy. http://www.fao.org/docrep/013/i1757e/i1757e00.htm (accessed on 19.10.2017).

[17] Gautam, A. P., Webb, E. L., Shivakoti, G., Zoebisch, M. (2003): Land use dynamics and landscape change pattern in a mountain watershed in Nepal. - Agriculture, Ecosystems \& Environment 9(1-3): 83-96.

[18] Güneş Şen, S. (2015): The disposition and characteristics of precipitation at different stand structures in Kastamonu-Daday region. - Msc. Thesis, Kastamonu University, Graduate School of Natural and Applied Sciences, Kastamonu.

[19] Güneş Şen, S., Aydın, M. (2017): Evaluation of land use conditions of ponds at Taşköprü. - International Taşköprü Pompeiopolis Science Cultural Arts Research Symposium, April 10-12: Taşköprü-Kastamonu, Turkey. https://yadi.sk/d/soS-JxsS3RMM6v.

[20] Hansen, M. C., Stehman, S. V., Potapov, P. V. (2010): Quantification of global gross forest cover loss. - Proceedings of the National Academy of Sciences of the United States 107(19): 8650-8655.

[21] Harris, N., Brown, S., Hagen, S., Saatchi, S., Pertova, S., Salas, W., et al. (2012): Baseline map of carbon emissions from deforestation in tropical regions. - Science 336(6088): 1573-1576.

[22] Harvey, B. J. (2016): Human-caused climate change is now a key driver of forest fire activity in the western United States. - Proceedings of the National Academy of Sciences 113(42): 11649-11650.

[23] Houghton, R. (2012): Carbon emissions and the drivers of deforestation and forest degradation in the tropics. - Current Opinion in Environmental Sustainability 4(6): 597603 . 
[24] Kadıoğulları, A. İ., Başkent, E. Z. (2008): Spatial and temporal dynamics of land use pattern in Turkey: a case study in Gümüşhane. - Environmental Monitoring and Assessment 138: 289-303.

[25] Kaplan, J. O., Krumhardt, K. M., Zimmermann, N. (2009): The prehistoric and preindustrial deforestation of Europe. - Quaternary Science Reviews 28 (27-28): 30163034.

[26] Karahalil, U., Kadıogulları, A. I., Başkent, E. Z., Köse, S. (2009): The spatiotemporal forest cover changes in Köprülü Canyon National Park (1965-2008). - African Journal of Biotechnology 8(18): 4495-4507.

[27] Kucuk, O., Topaloglu, O., Altunel, A. O., Cetin, M. (2017): Visibility analysis of fire lookout towers in the Boyabat State Forest Enterprise in Turkey. - Environmental Monitoring and Assessment 189(7): 329.

[28] Küre Mountains National Park (KMNP) (2017): Küre Mountains. http://www.kdmp.gov.tr/sayfa/kure-daglari (accessed on 23.02.2018).

[29] Lele, N., Joshi, P. K. (2009): Analyzing deforestation rates, spatial forest cover changes and identifying critical areas of forest cover changes in North-East India during 19721999. - Environmental Monitoring and Assessment 156(1-4): 159-70. DOI: 10.1007/s10661-008-0472-6.

[30] Ochoa-Quintero, J. M., Gardner, T. A., Rosa, I., Barros Ferraz, S. F., Sutherland, W. J. (2015): Thresholds of species loss in Amazonian deforestation frontier landscapes. Conservation Biology 29(2): 440-451.

[31] Ostlund, L., Hörnberg, G., DeLuca, T. H., Liedgren, L., Wikström, P., Zackrisson, O. et al. (2015): Intensive land use in the Swedish mountains between AD 800 and 1200 led to deforestation and ecosystem transformation with long-lasting effects. - Ambio 44(6): 508-520.

[32] Özel, H. B., Ertekin, M. (2012): The change of stand structure in Uludağ fir (Abies nordmanniana subsp. bornmuelleriana Mattf.) forests along an altitudinal gradient. Kastamonu University Journal of Forestry Faculty 12(3): 96-104.

[33] Özel, H. B., Kirdar, E., Bilir, N. (2015): The effects of magnetic field on germination of the seeds of oriental beech (Fagus orientalis Lipsky.) and growth of seedlings. Agriculture \& Forestry/Poljoprivreda i Sumarstvo 61(3): 195-206.

[34] Öztürk, S., Ayan, S. (2015): Management alternatives in national park areas: The case of Ilgaz Mountain National Park. - eco.mont - Journal on Protected Mountain Areas Research 7: 37-44.

[35] Öztürk, S., Özdemir, Z. (2013): The effects of urban open and green spaces on life quality: a case study of Kastamonu. - Journal of Kastamonu University Faculty of Forestry 13(1): 109-116.

[36] Puyravaud, J. P. (2003): Standardizing the calculation of the annual rate of deforestation. - Forest Ecology and Management 177: 593-596.

[37] Schweizer, D. W., Cisneros, R. (2017): Forest fire policy: change conventional thinking of smoke management to prioritize long-term air quality and public health. - Air Quality, Atmosphere \& Health 10(1): 33-36.

[38] Seçkin, B. (1995): Amenajman ve silvikültür ilişkisi, ekonomi-ekoloji ilkesine uygun orman işletmeciliği özlemim. - Orman Mühendisliği Dergisi 2: 25-27.

[39] Sen, G., Bayramoglu, M. M., Toksoy, D. (2015): Spatiotemporal changes of land use patterns in high mountain areas of Northeast Turkey: a case study in Maçka. Environmental Monitoring and Assessment 187(8): 515. DOI 10.1007/s10661-015-47278.

[40] Sevik, H. (2012): Variation in seedling morphology of Turkish fir (Abies nordmanniana subsp. bornmulleriana Mattf). - African Journal of Biotechnology 11(23): 6389-6395.

[41] Sevik, H., Cetin, M., Kapucu, Ö. (2016): Effect of light on young structures of Turkish Fir (Abies nordmanniana subsp. bornmulleriana). - Oxidation Communications 39 (I-II): 485-492. 
[42] Sevik, H., Cetin, M., Kapucu, O., Aricak, B., Canturk, U. (2017): Effects of light on morphologic and stomatal characteristics of Turkish Fir needles (Abies nordmanniana subsp. Bornmulleriana Mattf.). - Fresenius Environmental Bulletin 26(11): 6579-6587.

[43] Simpson, I. A., Vésteinsson, O., Adderley, W. P., Mc Govern, T. H. (2003): Fuel resource utilization in landscapes of settlement. - Journal of Archaeological Science 30(11): 1401-1420.

[44] Šturm, T., Podobnikar, T. (2017): A probability model for long-term forest fire occurrence in the Karst forest management area of Slovenia. - International Journal of Wildland Fire 26(5): 399-412.

[45] Trbojevic, N., Mooney, D. E., Bell, A. J. (2012): A firewood experiment at Eiríksstaðir: A step towards quantifying the use of firewood for daily household needs in Viking Age Iceland. - Archaeologia Islandica 9: 29-40.

[46] Tunçtaner, K., Özel, H. B., Ertekin, M. (2007): According to urban landscape design, the determination of legislation and regulation for conservation of historical environment. International Journal of Bartın Forestry Faculty 9(11): 11-225.

[47] Turan, S. Ö., Günlü, A. (2010): Spatial and temporal dynamics of land use pattern response to urbanization in Kastamonu. - African Journal of Biotechnology 9(5): 640647.

[48] Turkish Statistical Institute (TUIK) (2017): Population of Kastamonu City. www.tuik.gov.tr (accessed on 23.08.2017).

[49] Tyukavina, A., Baccini, A., Hansen, M. C., Potapov, P. V., Stehman, S. V., Houghton, R. A., et al. (2015): Aboveground carbon loss in natural and managed tropical forests from 2000 to 2012. - Environmental Research Letters 10074002. DOI: 10.1088/17489326/10/7/074002.

[50] URL1 (2004): Natural Resources. https://www.ugc.ac.in/oldpdf/modelcurriculum/Chapter2.pdf (accessed on 01.11.2017).

[51] URL2 TC Kastamonu Valiliği (2016): Kastamonu doğal güzellikleri ve eko turizm merkezi. - http://www.kastamonu.gov.tr/doga-turizm (accessed on 03.10.2017).

[52] URL3 (2017): Sözcü newspaper. Kastamonu Haberi: Küre Dağları'nda yeni endemik tür belirlendi. - http://www.sozcu.com.tr/2017/gundem/son-dakika-haberi/kure-daglarindayeni-endemik-tur-belirlendi-1721562/ (accessed on 23.11.2017).

[53] URL4 Forestry General Directorate (2017): İllere göre orman varlığı. https://www.ogm.gov.tr/Sayfalar/Ormanlarimiz/Illere-Gore-Orman-varligi.aspx (accessed on 18.12.2017).

[54] URL5 T. C. Kuzey Anadolu Kalkınma Ajansı (2014): TR82 Düzey 2 bölgesi bölge planı 2014-2023 Kastamonu - Çankır1 - Sinop İleri. https://www.kuzka.gov.tr/paylasim/20160401_tr82_bolge_plani_(WEB).pdf (accessed on 23.11.2017).

[55] URL6 TEB Kobi Akademi (2006): İller için gelecek stratejileri Kastamonu Gelecek Stratejisi Sonuç Raporu. - https://www.teb.com.tr/document/kastamonu.pdf (accessed on 09.12.2017).

[56] Yigit, N., Sevik, H., Cetin, M., Kaya, N. (2016): Determination of the Effect of Drought Stress on the Seed Germination in Some Plant Species. - In: Rahman, I. M., Begum, Z. A., Hasegawa, H. (eds.) Water Stress in Plants, Chapter 3, pp. 43/62. INTECH Open Book Publisher, Vienna.

[57] Zengin, H., Değermenci, A. S., Bettinger, P. (2018): Analysis of temporal changes in land cover and landscape metrics of a managed forest in the West Black Sea region of northern Turkey: 1970-2010. - Journal of Forestry Research 29(1): 139-150. 